\title{
INTERPRETASI LAHAN RAWA YANG BELUM DIALIH FUNGSI MENGGUNAKAN CITRA LANDSAT 8
}

\author{
Faris Ade Irawan ${ }^{1}$, Ferry Sobatnu ${ }^{1}$ \\ faris.irawan1984@gmail.com
}

\author{
(1) Staf Pengajar Jurusan Teknik Sipil Politeknik Negeri Banjarmasin
}

\begin{abstract}
Ringkasan
Lahan rawa adalah lahan darat yang tergenang secara periodik atau terus menerus secara alami dalam waktu lama karena drainase yang terhambat. Menggunakan teknologi penginderaan jauh dapat mempermudah mengidentifikasi dan menganalisis suatu obyek dengan area yang besar tanpa kontak langsung terhadap obyek yang dikaji. Penelitian ini memperoleh hasil interpretasi satelit Landsat 8 dan klasifikasi lahan rawa yang secara fisik belum beralih fungsi. Dengan menggunakan metode klasifikasi terbimbing (Supervised Classification) dihasilkan luasan lahan rawa di daerah Kabupaten Barito Kuala pada Tahun 2015 dan sebarannya per kecamatan di Kabupaten tersebut. Hasil yang diperoleh dapat menjadi data tambahan untuk instansi pemerintah atau pihak pengelola yang terkait mengenai luasan daerah rawa di Kabupaten Barito Kuala dan dapat digunakan sebagai acuan untuk rencana lebih lanjut terhadap pemanfaatan lahan rawa dan penggunaan teknologi penginderaan jauh untuk monitoring lahan rawa. Berdasarkan hasil interpretasi dan klasifikasi terbimbing citra satelit Landsat 8 menggunakan sampel area yaitu Hutan Galam (melalueca leucadendra) dan vegetasi Purun Tikus (Eleocharis Dulcis) di lokasi penelitian di temukan yaitu, luas lahan rawa belum dialih fungsi mencapai $613.753 \mathrm{Km}^{2}$, yang tersebar di 12 Kecamatan. Hasil validasi lapangan menunjukan tingkat ketelitian interpretasi mencapai 80\% dari 10 lokasi pengujian.
\end{abstract}

Kata Kunci : Rawa, Interpretasi dan Klasifikasi

\section{PENDAHULUAN}

Kegiatan penelitian dilakukan di Kabupaten Barito Kuala. Letak astronomis Kabupaten Barito Kuala berada pada $2^{\circ} 29^{\prime} 50^{\prime \prime}$ - $3^{\circ} 30^{\prime} 18^{\prime \prime}$ Lintang Selatan dan $114^{\circ} 20^{\prime} 50^{\prime \prime}$ $114^{\circ} 50^{\prime} 18^{\prime \prime}$ Bujur Timur. Kabupaten Barito Kuala didominasi oleh daerah rawa datar kelerengan $0 \%-2 \%$ dan ketinggian elevasi berkisar antara 1-3 meter di atas permukaan laut.

Kabupaten Barito Kuala dikelilingi sungai dan rawa. Kondisi ini menyebabkan tanah daerah ini masuk kategori lahan gambut. Tingkat keasaman tanah di sana mencapai ph 3-5. Wilayah ini terdiri dari dua jenis tanah yang dominan, yaitu Aluvial sebesar 59,46\% dan selebihnya sekitar 40,54\% merupakan Organosol Glei Humus yang sebagian merupakan daerah yang tergenang terus menerus. (Mubekti, 2010).

Luas lahan rawa pasang surut di Indonesia diperkirakan 20,11 juta hektar terdiri dari 2,07 juta hektar lahan pasang surut potensial, 6,71 juta hektar lahan sulfat masam, 10.89 juta hektar lahan gambut, dan 0,44 juta hektar Iahan salin (Alihamsyah, 2002). Di Kalimantan Selatan luas lahan rawa pasang surut sekitar 182.990 hektar, diantaranya seluas 99.695 hektar berada di wilayah pemerintah Kabupaten Barito Kuala, dari jumlah tersebut yang sudah diusahakan atau beralih fungsi seluas 78.209 hektar (Diperta, 2007).

Untuk lahan rawa yang belum diusahakan bisa diketahui luasannya dengan metode interpretasi dengan menggunakan citra satelit. Obyek pada citra diidentifikasi menggunakan beberapa unsur untuk bisa disimpulkan, misalnya lahan rawa yang belum beralih fungsi diidentifikasi melalui tekstur, warna, bentuk dan sebagainya, maka pada area berbeda dengan ciri yang sama akan terklasifikasi sebagai satu jenis obyek.

Menggunakan teknologi penginderaan jauh dapat mempermudah mengidentifikasi dan menganalisis suatu obyek pada area yang besar tanpa kontak langsung terhadap obyek yang dikaji. Hasil interpretasi dan klasifikasi lahan rawa akan menunjukan berapa luasan lahan rawa di daerah Kabupaten Barito Kuala. Hasil yang diperoleh dapat menjadi data tambahan untuk instansi pemerintah mengenai luasan daerah rawa di Kabupaten Barito Kuala. Hasil identifikasi tersebut dapat digunakan sebagai acuan untuk rencana lebih lanjut mengenai pemanfaatan lahan dan kepentingan lainnya. Lebih spesifiknya, lahan rawa dibagi menjadi lahan rawa yang sudah 
beralih fungsi dan lahan rawa yang belum beralih fungsi. Obyek yang diteliti adalah lahan rawa yang belum beralih fungsi.

Tujuan dari penelitian ini adalah menginterpretasi citra satelit Landsat $8 \mathrm{OLI} /$ TIRS untuk identifikasi lahan rawa dan mengklasifikasikan lahan rawa pada citra satelit yang secara fisik belum beralih fungsi.

\section{METODE PENELITIAN}

Penelitian kerapatan mangrove menggunakan satelit Landsat 8 OLI / TIRS tahun 2015, komposit saluran (band) yang digunakan adalah RGB 5-6-4 false color, melakukan interpretasi dan klasifikasi terbimbing (Supervised Classification) merupakan proses pengambilan beberapa sampel piksel untuk masing - masing kelas atau obyek. Sampel tersebut digunakan untuk mendapatkan karakteristik nilai piksel pada masing - masing kelas atau obyek. Hasil interpretasi dan klasifikasi tersebut menghasilkan peta lahan rawa belum dialih fungsi sementara (tentatif). Dilakukan uji ketelitian interpretasi melalui validasi menggunakan ke titik-titik sampel yang telah ditentukan, tahapan selanjutnya dilakukan proses interpretasi ulang (re-interpretasi) pada lokasi-lokasi yang dianggap kurang akurat untuk menghasilkan peta tematik lahan rawa belum dialih fungsi.

Secara sistematis proses penelitaian yang dilakukan digambarkan melalui diagram alir penelitian sebagai berikut:

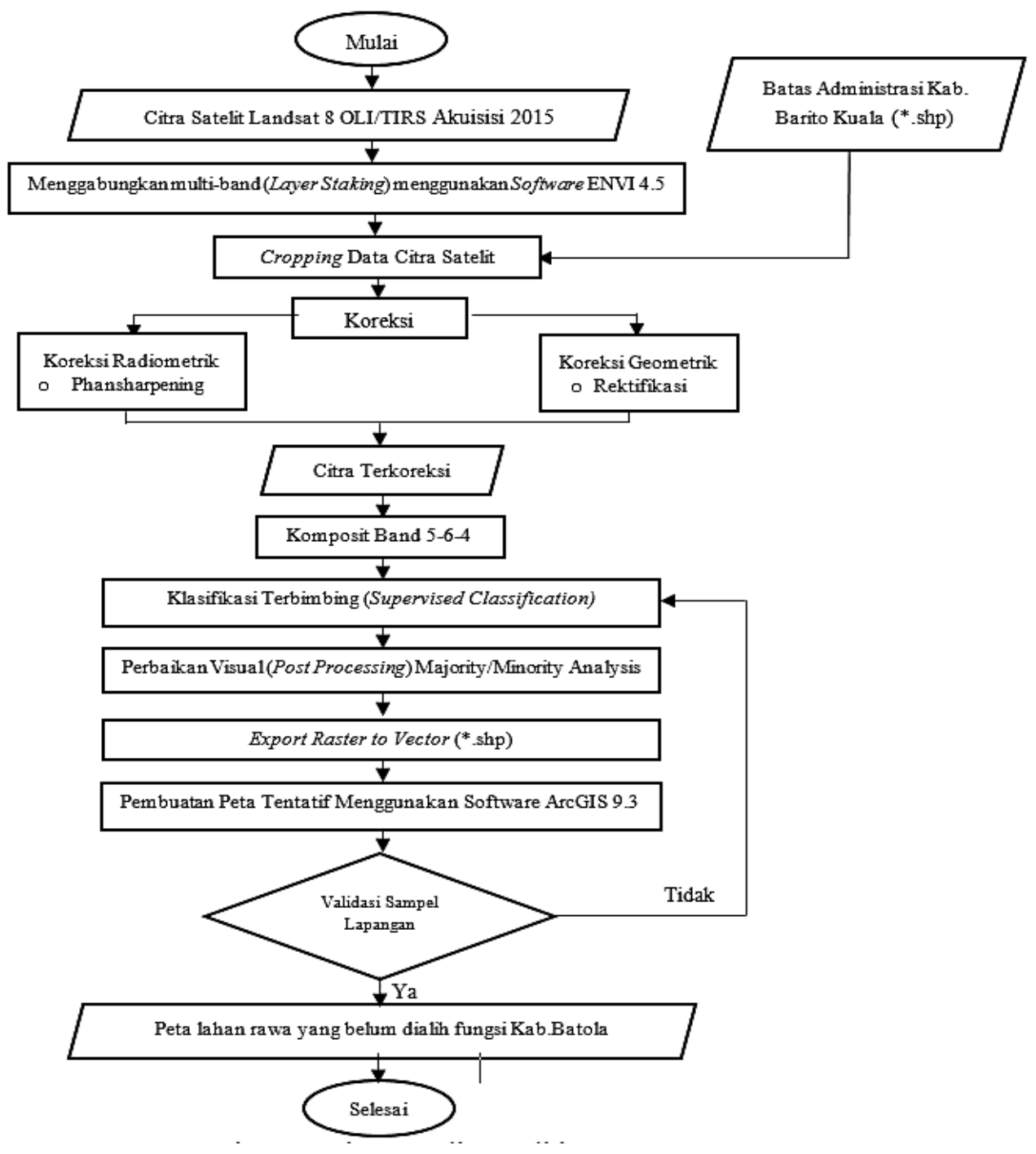

Gambar 1 : Diagram Alir Penelitian 


\section{METODE PENGOLAHAN DATA DAN ANALISIS}

Adapun tahapan pengolahan dan analisis yang diterapkan adalah sebagai berikut:

1. Layer Staking merupakan proses pembuatan multi-band pada suatu file citra dengan cara menggabungkan image dari band - band yang terpisah (band 1 band 11) menjadi satu file.

2. Mosaic citra merupakan proses menggabungkan 2 atau lebih scenes citra. Proses ini sangat penting dilakukan apabila wilayah penelitian terdiri dari 2 atau lebih scenes citra.

3. Cropping citra dilakukan untuk mendapatkan daerah penelitian dengan maksud untuk dapat melakukan pengolahan data yang lebih terfokus, terinci dan teroptimal. Pemotongan citra yaitu memperkecil daerah yang akan dikaji sesuai dengan area of interest.

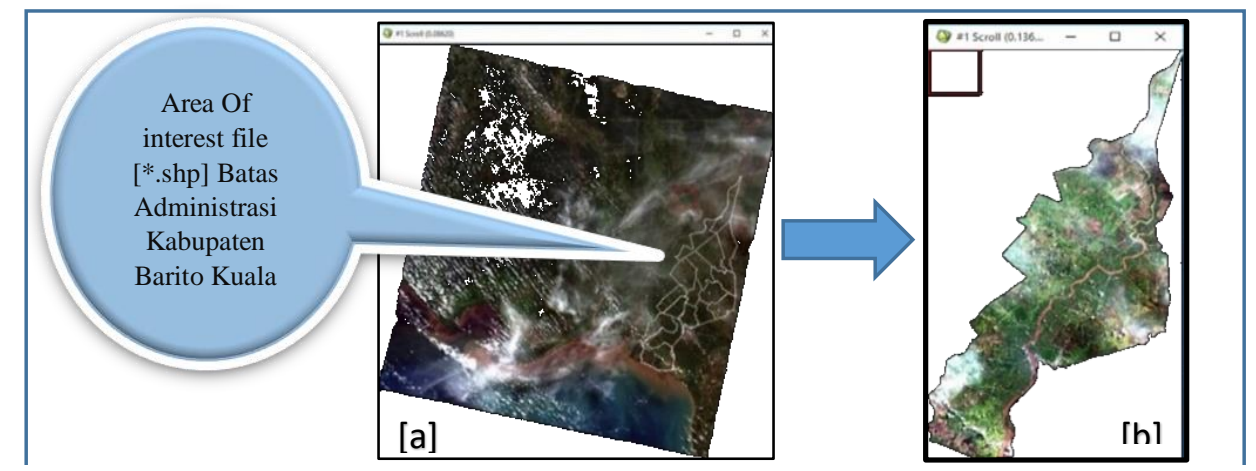

Gambar 2. [a] 1 scene citra landsat (L8 OLI/TIRS) hasil download di situs USGS yang di overlay dengan ROI; [b] citra landsat (L8 OLI/TIRS) Kab. Barito Kuala hasil cropping dengan komposit saluran RGB 3-2-1 True Color

1. Sebelum dilakukan pengolahan data citra diperlukan proses koreksi geometrik yang bertujuan untuk memperbaiki posisi obyek dalam citra akibat distorsi ke posisi sebenarnya di permukaan bumi.

2. Komposit band merupakan cara yang paling umum untuk menonjolkan masing masing keunggulan saluran secara serentak dalam satu display, sehingga memudahkan pengguna dalam menginterpretasikan citra. Pada penelitian ini menggunakan komposite band 5-6-4 (Gambar 3.), karena ketiga saluran band tersebut memiliki aplikasi yang kuat terhadap pemisahan jenis vegetasi. Tabel 1 berikut adalah karakteristik saluran band 5-6-4 :

Tabel 1 Karakteristik Saluran band 5-6-4

\begin{tabular}{|c|c|c|l|}
\hline $\begin{array}{c}\text { Saluran } \\
\text { Band }\end{array}$ & $\begin{array}{c}\text { Panjang Saluran } \\
(\boldsymbol{\mu m})\end{array}$ & $\begin{array}{c}\text { Resolusi } \\
\text { Spasial }\end{array}$ & \multicolumn{1}{|c|}{ Aplikasi } \\
\hline 5 & $0.845-0.885$ & 30 Meter & $\begin{array}{l}\text { Saluran yang peka terhadap kandungan air dalam tanah dan } \\
\text { vegetasi, menembus awan tipis, membedakan jenis vegetasi. }\end{array}$ \\
\hline 6 & $1.560-1.660$ & 30 Meter & $\begin{array}{l}\text { Saluran penting untuk pemetaan termal, pembedaan kelembaban } \\
\text { tanah, analisis gangguan vegetasi, klasifikasi vegetasi. }\end{array}$ \\
\hline 4 & $0.630-0.680$ & 30 Meter & $\begin{array}{l}\text { Saluran terpenting untuk membedakan kandungan biomassa, } \\
\text { identifikasi jenis tanaman, membedakan tanah dan tanaman, } \\
\text { pemetaan garis pantai. }\end{array}$ \\
\hline
\end{tabular}

(Sabins, 1987 : 86 dan Liiesand \& Kiefer, 1994 : 468) 


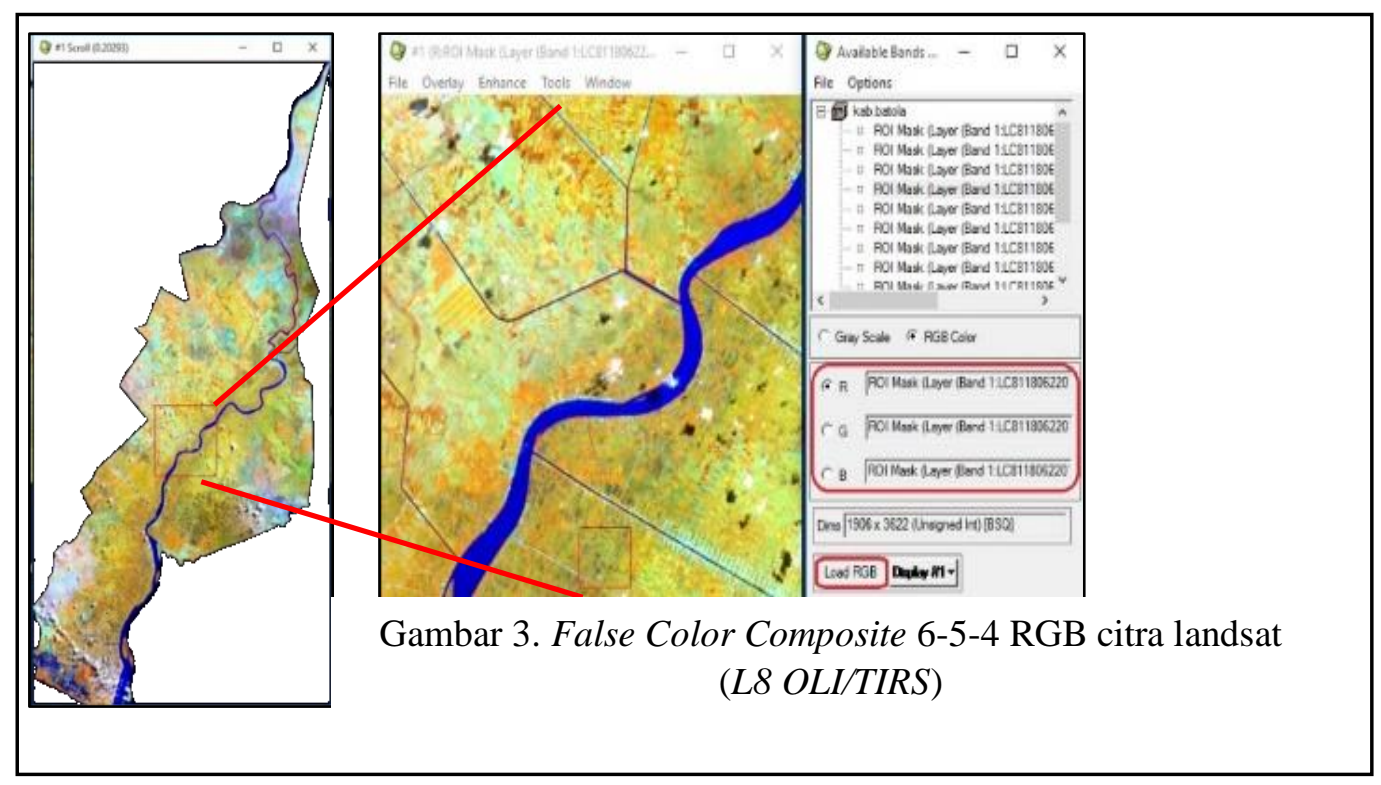

1. Klasifikasi Terbimbing merupakan proses pengambilan beberapa sampel piksel untuk masing - masing kelas atau obyek. Sampel tersebut digunakan untuk mendapatkan karakteristik nilai piksel pada masing - masing kelas atau obyek. Seperti yangg terilhat pada Gambar 4 .

2. Perbaikan Visual (Post Processing) adalah memperbaiki visualisasi dari hasil klasifikasi, nilai piksel yang merupakan kelas minoritas akan diminimalisir dan digabungkan kedalam kelas mayoritas.

3. Pembuatan peta tentatif, Export Raster to Vector. Melakukan interpretasi ulang (reinterpretasi) pada lokasi-lokasi yang mengalami perbaikan setelah ground truth
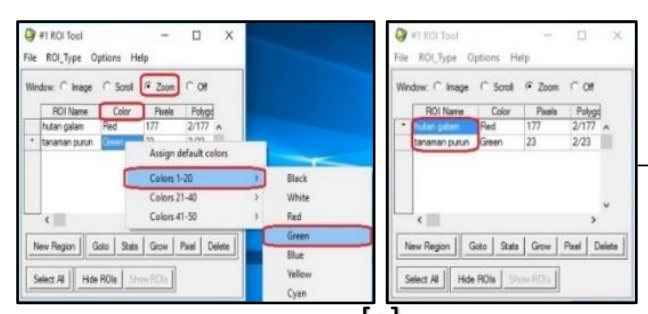

[a]

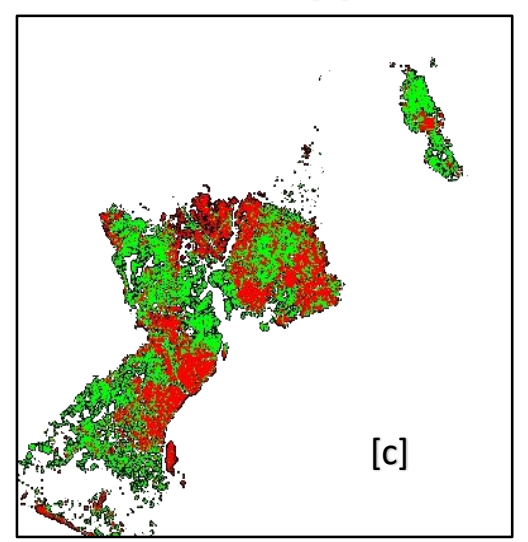

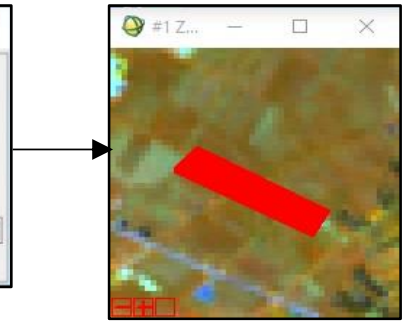

(1) Sampel Hutan Galam

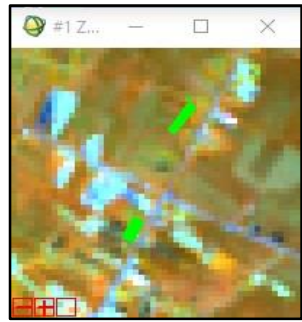

(2) Sampel Vegetasi Purun Tikus

[b]

Gambar 4. [a] pembuatan tabel dan pewarnaan kelas untuk sampel; [b] penentuan sampel obyek pada citra landsat; [c] hasil klasifikasi terbimbing lahan rawa belum dialih fungsi di Kabupaten Barito Kuala 


\section{HASIL DAN PEMBAHASAN}

\section{Hasil Interpretasi dan Klasifikasi Terbim- bing (Supervised Clasification)}

Citra Landsat 8 OLI/TIRS Akuisisi 2015 di lokasi penelitian merupakan citra satelit archieve gratis (free download) terbaik yang disediakan oleh website resmi USGS (United States Geological Survey). Di lokasi penelitian yaitu Kabupaten Barito Kuala merupakan salah satu daerah yang memiliki lahan rawa cukup luas. Pada tahun 2015 Kabupaten Barito Kuala mengalami kemarau panjang dan musibah kebakaran lahan yang cukup banyak, sehingga proses interpretasi citra secara visual berdasarkan resolusi spektral menggunakan kombinasi saluran 5-6-4 RGB false color menjadi terganggu dan cukup kesulitan dalam menentukan sampel area.
Obyek pada citra akan masuk ke dalam golongan unclassified apabila salah satu dari beberapa unsur interpretasi yang dimilikinya berbeda dengan obyek yang dikelaskan. Contoh lahan yang unclassified seperti lahan rawa yang belum dialih fungsi, yang pada tanggal pengambilan citra mengalami kebakaran lahan, maka tampilan warna pada citra akan berbeda dan obyek tersebut tidak akan dikelaskan sebagai lahan rawa yang belum dialih fungsi seperti contoh obyek yang sudah ditentukan sebagai sampel area.

Pada gambar 5, warna merah merupakan lahan rawa yang belum beralih fungsi, dimana sampel area yang digunakan adalah kenampakan hutan galam (melalueca leucadendra) dan vegetasi purun tikus (Eleocharis Dulcis).

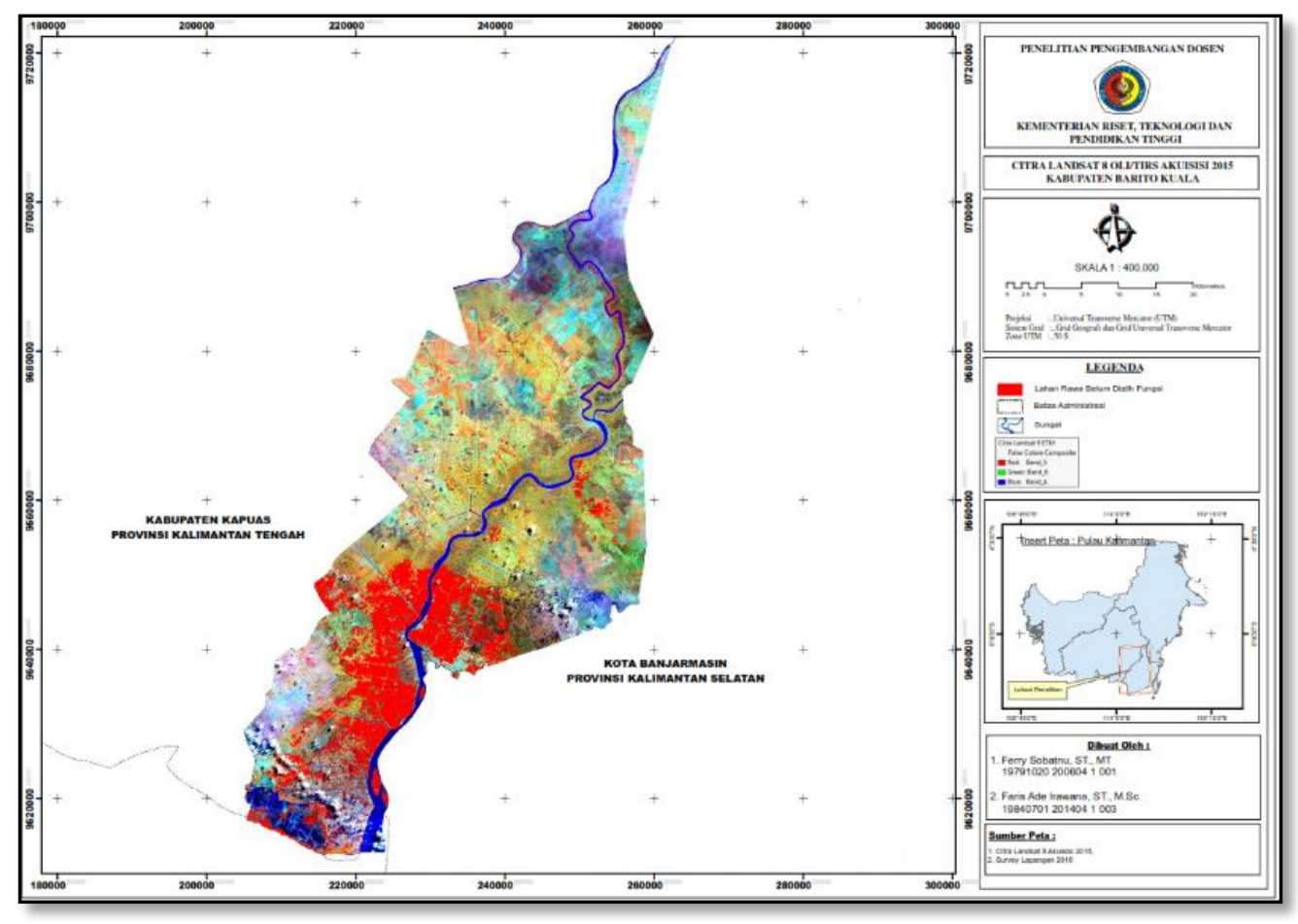

Gambar 5. Citra Landsat 8 kombinasi saluran 5-6-4 RGB false color.

\section{Pembuatan Peta Tentatif Dan Validasi Lapangan}

Citra satelit yang telah diinterpretasi dan telah dilakukan klasifikasi terbimbing menggunakan metode sampel area, selanjutnya divalidasi kebenarannya melalui cek lapangan (ground truth). Diperlukan peta tentatif (sementara) untuk proses validasi tersebut, menggunakan metode random sampling, ditentukan 10 titik sampel yang akan divalidasi secara langsung dilapangan. Titik sampel yang dipilih berdasarkan kemudahan akses menuju lokasi tersebut dan diharapkan mampu mewakili seluruh hasil interpretasi dan klasifikasi.

Validasi lapangan dilakukan dengan menetapkan sebanyak 10 titik - titik sampel hasil dari interpretasi data citra. Berdasarkan hasil Ground Check lapangan menunjukkan kesalahan di dua (2) titik sampel yaitu pada titik 4 dan 6, dan delapan (8) sampel benar pada titik 1, 2, 3, 5, 7, 8, 9 dan 10. Berikut adalah contoh sampel benar dan sampel salah. Keseluruhan sampel ada pada data terlampir. 
Tabel 2. Koordinat Hasil Validasi Lapangan

\begin{tabular}{|c|c|c|c|c|c|}
\hline No & Peta Tentatif & Lapangan & $X$ & $Y$ & Hasil \\
\hline 1 & Rawa Belum Dialih Fungsi & Rawa Belum Dialih Fungsi & 234401.355376 & 9640620.10835 & Benar \\
\hline 2 & Rawa Belum Dialih Fungsi & Rawa Belum Dialih Fungsi & 234371.705447 & 9641646.47876 & Benar \\
\hline 3 & Rawa Belum Dialih Fungsi & Rawa Belum Dialih Fungsi & 230998.507594 & 9642968.54479 & Benar \\
\hline 4 & Rawa Belum Dialih Fungsi & Sawah & 229973.487662 & 9643597.50473 & Salah \\
\hline 5 & Rawa Belum Dialih Fungsi & Rawa Belum Dialih Fungsi & 228558.255039 & 9644118.04349 & Benar \\
\hline 6 & Rawa Belum Dialih Fungsi & Sawah & 226184.181303 & 9646854.49349 & Salah \\
\hline 7 & Rawa Belum Dialih Fungsi & Rawa Belum Dialih Fungsi & 235689.596417 & 9642213.89212 & Benar \\
\hline 8 & Rawa Belum Dialih Fungsi & Rawa Belum Dialih Fungsi & 235500.771734 & 9642847.95852 & Benar \\
\hline 9 & Rawa Belum Dialih Fungsi & Rawa Belum Dialih Fungsi & 236673.77342 & 9640976.13794 & Benar \\
\hline 10 & Rawa Belum Dialih Fungsi & Rawa Belum Dialih Fungsi & 237849.905574 & 9640730.96637 & Benar \\
\hline
\end{tabular}

\section{Sumber : Survey Lapangan Juni 2016}

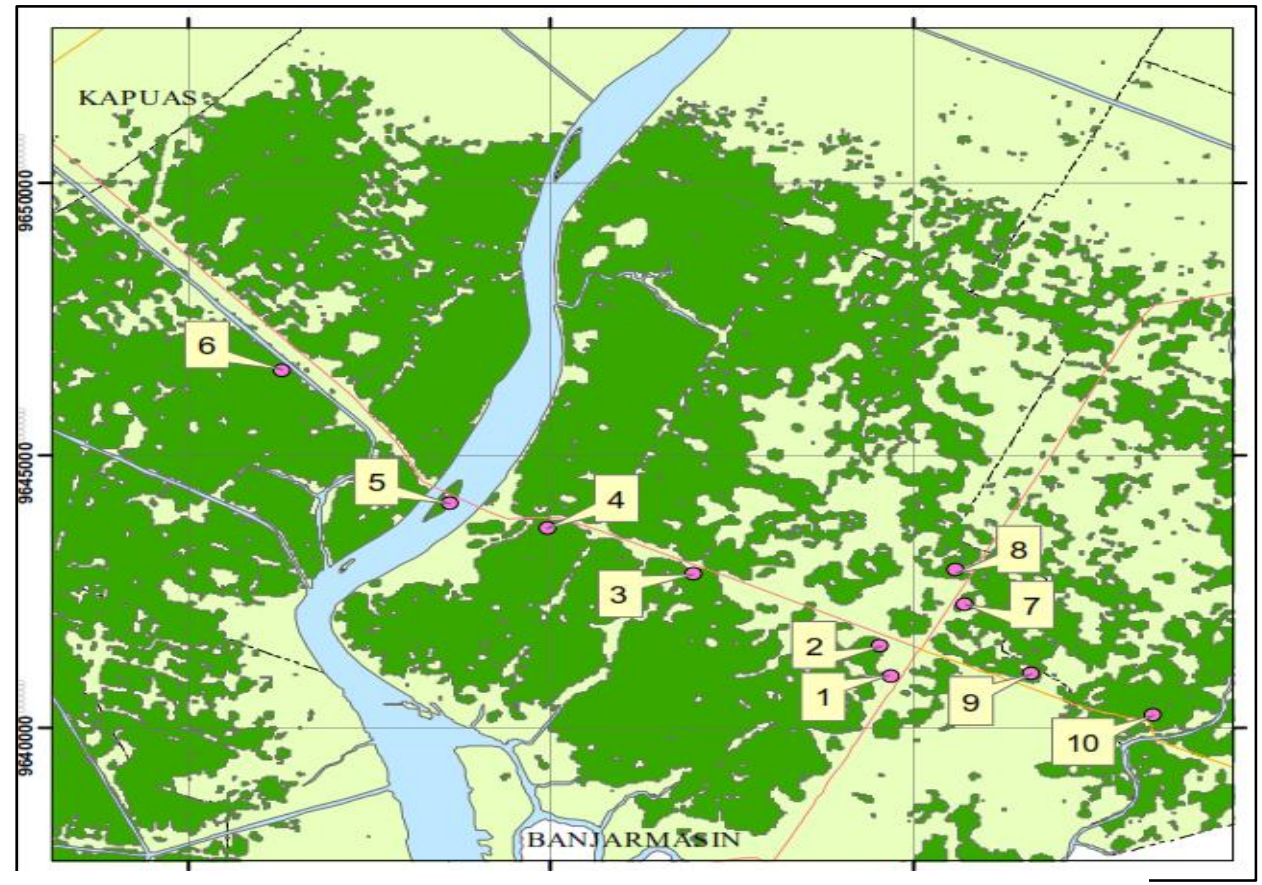

Gambar 6. Hasil Peta Tentatif Lahan Rawa Belum Dialih Fungsi Kabunaten Barito Kuala

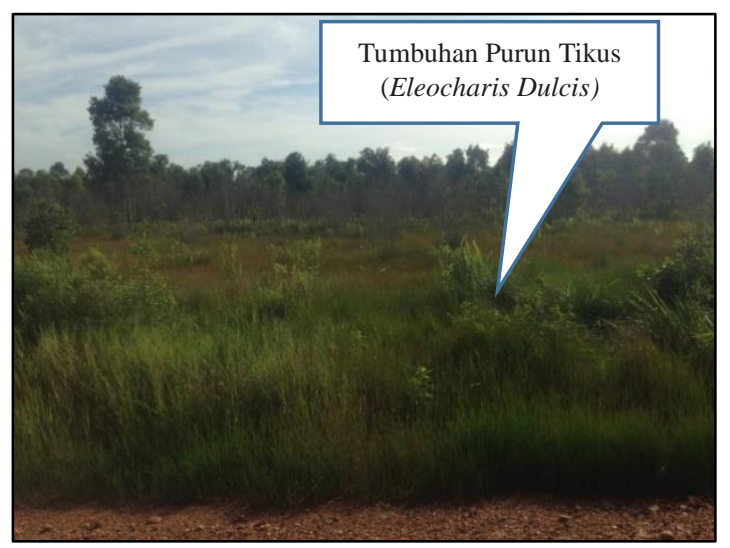

Gambar 7. Foto Sampel Benar di Titik 10. Koordinat:

$\mathrm{X}=237849.905574$; $\mathrm{Y}=9640730.96637$

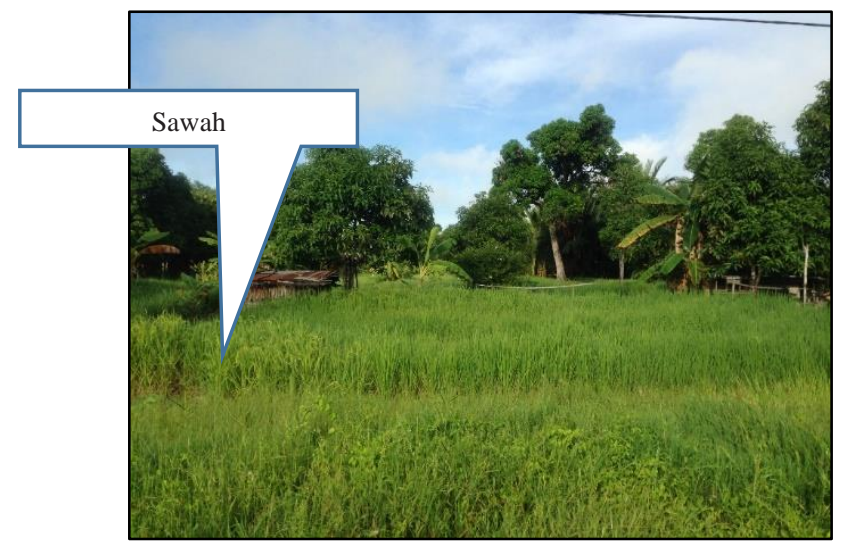

Gambar 8. Foto Sampel Salah di Titik 6.

Koordinat:

$\mathrm{X}=226184.181303$;

$\mathrm{Y}=9646854.49349$ 


\section{Uji Akurasi Hasil Interpretasi Citra}

Untuk menguji kebenaran interpretasi citra yang telah dilakukan, maka diperlukan diadakannya cek lapangan untuk membandingkan kondisi dilapangan dan hasil interpretasi citra.

Dalam penelitian ini menggunakan rumus ketelitian hasil interpretasi Short (1982) dalam Sutanto (1986) yaitu :

Ketelitian Hasil Interpretasi

$=\frac{\text { Jumlah Sampel yang Benar }}{\text { Jumlah Seluruh Sampel }} \times 100 \%$

Jumlah Seluruh Sampel : 10

Jumlah Sampel yang Benar : 8

Ketelitian Hasil Interpretasi $\frac{8}{10} \times 100 \%$

$$
=0,8 \times 100 \%
$$$$
=80 \%
$$

Berdasarkan (Purwadhi 2001), Nilai ketelitian yang diharapkan nantinya harus memenuhi syarat lebih besar dari $70 \%$, sehingga dari nilai yang didapatkan tersebut merupakan pembuktian terhadap nilai kevalidan data citra.

\section{Rekapitulasi Luasan dan Peta Lahan Rawa yang Belum Dialih Fungsi}

Hasil dari keseluruhan proses yang dilakukan akan menghasilkan sebuah peta seperti gambar 5.6 yang menyajikan area lahan rawa yang belum dialih fungsi di Kabupaten Barito Kuala. Tabel 5.2 adalah luasan per Kecamatan dari lawan rawa yang belum beralih fungsi di Kabupaten Barito Kuala berdasarkan hasil interpretasi dan klasifikasi citra satelit landsat tahun 2015, dengan total luas $613.753 \mathrm{Km}^{2}$.

Tabel 3. Luasan Per Kecamatan Lahan Rawa Belum Beralih Fungsi Kab.Batola

\begin{tabular}{|r|l|l|}
\hline No & Kecamatan & $\begin{array}{l}\text { Luas } \\
\left(\mathrm{KM}^{2}\right)\end{array}$ \\
\hline 1 & $\begin{array}{l}\text { ALALAK } \\
\text { BARANGAS }\end{array}$ & 64.219 \\
\hline 2 & ANJIR MUARA & 71.627 \\
\hline 3 & ANJIR PASAR & 71.671 \\
\hline 4 & BARAMBAI & 0.060 \\
\hline 5 & BELAWANG & 57.276 \\
\hline 6 & CERBON & 7.411 \\
\hline 7 & JEJANGKIT & 0.395 \\
\hline 8 & MANDASTANA & 69.030 \\
\hline 9 & MEKARSARI & 102.607 \\
\hline 10 & RANTAU BADAUH & 6.478 \\
\hline 11 & TABUNGANEN & 38.635 \\
\hline 12 & TAMBAN & 124.345 \\
\hline \multicolumn{2}{|c|}{ Total $=$} & 613.753 \\
\hline
\end{tabular}

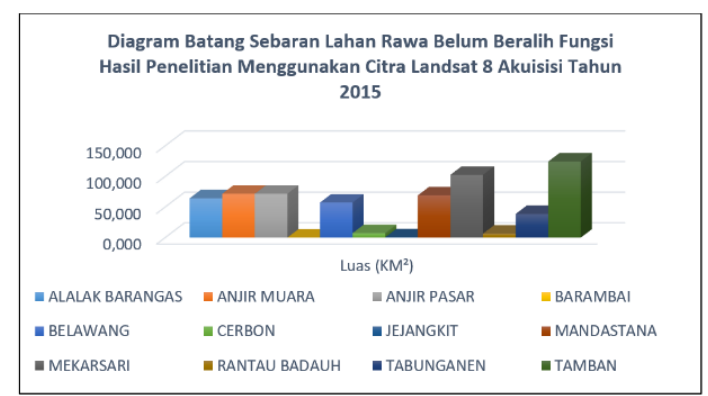

Gambar 9. Diagram Batang Rekapitulasi Luasan Lahan Rawa

\section{Peta}

Penelitian ini menghasilkan peta tematik Peta Lahan Rawa yang Belum Dialih Fungsi di Kabupaten Barito Kuala, Kalimantan Selatan. Peta tematik ini dibuat berdasarkan hasil interpretasi citra Landsat yang kemudian dilakukan validasi lapangan.

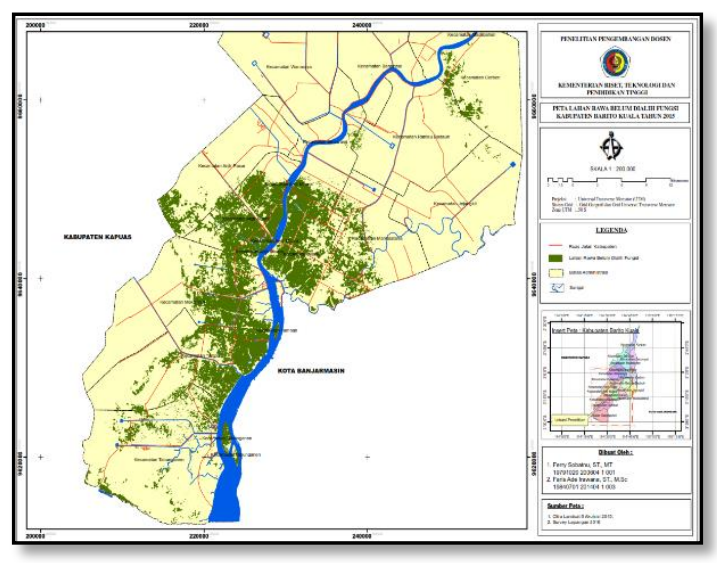

Gambar 10. Peta Lahan Rawa yang Belum Dialih Fungsi per Kecamatan di Kabupaten Barito Kuala

\section{KESIMPULAN}

Berdasarkan hasil penelitian ini dapat disimpulkan bahwa :

1. Data citra satelit Landsat 8 OLI/TIRS dapat digunakan untuk menginterpretasikan lahan rawa yang belum dialih fungsi di Kabupaten Barito Kuala, dengan menggunakan metode Klasifikasi Terbimbing (Supervised Classification) dan dengan memanfaatkan komposite band 56-4, karena kombinasi band tersebut diaplikasikan untuk mengidentifikasi lahan tanah dan air.

2. Dari 10 titik sampel lapangan di dapat 8 titik sampel lapangan yang benar maka hasil 
perhitungan ketelitian hasil interpretasi didapat nilai ketelitian sebesar $80 \%$.

3. Berdasarkan hasil penelitian menggunakan citra Landsat 8 akuisisi tahun 2015, luasan lahan rawa yang belum beralih fungsi di Kabupaten Barito Kuala $613.753 \mathrm{Km} 2$ yang tersebar di 12 Kecamatan.

\section{SARAN}

Berdasarkan proses sampai dengan hasil yang diperoleh dari penelitian ini dapat ditarik beberapa saran sebagai berikut :

1. Perbaikan pada penelitian yang sama, perlu menggunakan data citra dengan resolusi tinggi untuk lebih mudah dalam menginterpretasikan suatu unsur yang akan di teliti.

2. Meningkatkan ketelitian dalam menginterpretasikan citra, diperlukan data citra dengan akuisisi tanggal dan tahun terbaru karena akan lebih sedikit perbedaan dengan keadaan di lokasi saat validasi lapangan dilakukan

\section{PUSTAKA}

[1] Alihamsyah, T. 2002. Optimalisasi Pendayagunaan Lahan Rawa Pasang Surut. Makalah Seminar Nasional Optimalisasi Pendayagunaan Sumberdaya Lahan di Cisarua. Puslitbang Tanah dan Agroklimat.

[2] Dinas Tanaman Pangan dan Holtikultura. 2007. Laporan Tahunan Dinas Pertanian Tanaman Pangan dan Holtikultura Provinsi Kalimantan Selatan, Banjarbaru.

[3] Mubekti, 2010. Evaluasi Lahan Untuk Zonasi Komoditas Unggulan Pertanian Kasus Kawasan Rawa Pasang Surut Kabupaten Batola. Jurudan teknik Lingkungan . Vol 11. Jakarta.

[4] Purwadhi, Sri Hardiyanti. 2001. Interpretasi Citra Digital. PT Grasindo. Jakarta.

[5] Sabins, F.F. Jr., 1987. Principle and interpretation, $3^{\text {rd }}$ ed., W.H. Freeman and Co., San Francisco.

[6] Sutanto, 1986. Pengantar Peninderaan Jauh Jilid I. UGM Press, Yogyakarta.

[7] Sabins, F.F. Jr., 1987. Principle and interpretation, $3^{\text {rd }}$ ed., W.H. Freeman and Co., San Francisco. 